\title{
PENINGKATAN KUALITAS PELAYANAN PUBLIK BIDANG VERIFIKASI STANDAR UKURAN DAN KALIBRASI ALAT UKUR METROLOGI TEKNIS DENGAN PENDEKATAN LEAN SIX SIGMA
}

\author{
Juliani ${ }^{*}$, Catharina Badra Nawangpalupi \\ Program Magister Teknik Industri, Fakultas Teknologi Industri, Universitas Katolik Parahyangan \\ Email: j4pussung@gmail.com; katrin@unpar.ac.id
}

Artikel masuk : 19-08-2020

\author{
Artikel direvisi : 15-10-2020 \\ *Penulis Korespondensi
}

Artikel diterima : 05-11-2020

\begin{abstract}
Abstrak -- Pelayanan verifikasi standar ukuran dan kalibrasi alat ukur metrologi teknis merupakan salah satu pelayanan publik. Pelayanan ini belum mencapai sasaran mutu yang ditetapkan dan masih terdapat pemborosan. Penelitian ini membahas penerapan Lean Six Sigma pada pelayanan publik terutama pada pelayanan verifikasi standar ukuran dan kalibrasi alat ukur metrologi teknis. Tools yang digunakan dalam penelitian ini yaitu Value Stream Mapping (VSM) dari Lean digabungkan dengan Diagram Fishbone dan Failure Mode and Effects Analysis (FMEA) dari Six Sigma. Penelitian ini menggunakan data primer (dengan wawancara dan pengamatan langsung dilapangan) dan data sekunder (dengan mengambil data kinerja dan data pengaduan pelanggan tahun 2018-2019). Hasil penelitian menunjukkan bahwa implementasi Lean Six Sigma mampu mengidentifikasi penyebab keterlambatan, pemborosan dan menghasilkan berbagai rekomendasi perbaikan. Dua rekomendasi yang dapat diterapkan pada tahun 2019, yaitu penambahan 1 orang pegawai di Laboratorium Panjang dan map order beserta Standar/alat masuk laboratorium max $H+1$ telah mampu meningkatkan level sigma pada kinerja laboratorium yang merupakan salah satu bagian dari kinerja pelayanan. Dari perbaikan saat ini, dapat dilakukan pengembangan lebih lanjut yaitu menggabungkan data identifikasi pemborosan dari VSM dan Diagram Fishbone ke dalam FMEA untuk perbaikan dan analisis yang lebih komprehensif.
\end{abstract}

.Kata kunci: Lean Six Sigma; Value Stream Mapping (VSM); Diagram Fishbone; Failure Mode and Effects Analysis (FMEA)

\begin{abstract}
Service of measurement standards verification and technical metrology measurement tools calibration is one of the public services. This service has not achieved the quality objectives set, and there is still waste. This study discusses the application of Lean Six Sigma in public services, especially in measurement standards verification and technical metrology measurement tools calibration. Tools used in this research are Value Stream Mapping (VSM) from Lean combined with Fishbone Diagram and Failure Mode and Effects Analysis (FMEA) from Six Sigma. This study uses primary data (with interviews and direct field observations) and secondary data (by taking service performance data and customer complaint data for 2018-2019). The research results show that the implementation of Lean Six Sigma can identify the causes of delays, waste and produce various recommendations for improvement. Two recommendations that can be implemented in 2019, namely the addition of 1 employee in the Panjang Laboratory and the entry of order map along with the standard/equipment in laboratory max $\mathrm{H}+1$ have been able to increase the sigma level in laboratory performance which is one part of service performance. Further development can be carried out from the current improvement, namely combining waste identification data from VSM and Fishbone diagrams into FMEA for more comprehensive improvement and analysis.
\end{abstract}

Keywords: Lean Six Sigma; Value Stream Mapping (VSM); Fishbone Diagrams; Failure Mode and Effects Analysis (FMEA) 


\section{PENDAHULUAN}

Pelayanan publik adalah kegiatan atau rangkaian kegiatan dalam rangka pemenuhan kebutuhan pelayanan sesuai dengan peraturan perundang-undangan bagi setiap warga negara dan penduduk atas barang, jasa, dan/atau pelayanan administratif yang disediakan oleh penyelenggara pelayanan publik (Undang-Undang Republik Indonesia, 2009). Penyelenggara Pelayanan Publik wajib menyusun, menetapkan, dan menerapkan Standar Pelayanan dengan mengikutsertakan Masyarakat dan Pihak Terkait (Presiden Republik Indonesia, 2012). Standar Pelayanan dimaksud merupakan tolok ukur yang dipergunakan sebagai pedoman penyelenggaraan pelayanan dan acuan penilaian kualitas pelayanan.

Keseriusan pemerintah dalam hal kualitas juga dilatarbelakangi pada konsep dan prinsip kepemerintahan yang baik (good governance) sebagai parameter penilaian tingkat kemajuan penyelenggaraan kepemerintahan (Peraturan Menteri Pendayagunaan Aparatur Negara, 2009). Konsep Good governance inilah yang memberi dasar bagi siapa pun yang berperan dan peran apapun yang dijalankan dalam penyelenggaraan pemerintahan dituntut untuk lebih berorientasi ke pelayanan publik yang semakin baik. Dengan kata lain, tidak ada kepemerintahan yang dapat disebut lebih atau semakin baik jika tidak ada bukti bahwa pelayanan publik semakin baik dan semakin berkualitas..

Dampak kualitas pelayanan publik dalam berbagai bidang diantaranya pada bidang ekonomi, buruknya pelayanan publik akan berimplikasi pada penurunan investasi yang dapat berakibat terhadap pemutusan hubungan kerja pada industri-industri dan tidak terbukanya lapangan kerja baru yang juga akan berpengaruh terhadap meningkatnya angka pengangguran (Mahsyar, 2011). Akibat lebih lanjut dari masalah ini adalah timbulnya kerawanan sosial. Perbaikan pelayanan publik akan bisa memperbaiki iklim investasi yang sangat diperlukan bangsa ini untuk dapat segera keluar dari krisis ekonomi yang berkepanjangan.

Merujuk pada artikel OMBUDSMAN oleh Wahid (2019), dari lima daerah di Sumatera Barat yang dinilai tahun ini, tidak satupun daerah yang mendapat rapor hijau/kepatuhan tinggi. Kabupaten Dharmasraya mendapat rapor kuning dengan nilai 79,62 , perolehan nilai yang sebetulnya sangat tipis untuk dapat memperoleh rapor hijau. Kabupaten 50 Kota dengan rapor kuning dengan nilai 55,25. Tiga daerah mendapat rapor merah, Solok Selatan dengan nilai 48,17, Kabupaten Solok dengan nilai 43,50 dan Mentawai dengan nilai terendah 25,18. Secara umum, tentu capaian ini sangat buruk, karena tidak ada yang meraih rapor hijau. Hal senada juga disampaikan oleh CNN Indonesia (2019), penilaian Ombudsman dilakukan terhadap empat kementerian, tiga lembaga, enam pemerintah provinsi, 36 pemerintah kota dan 215 pemerintah kabupaten. Survei ini mencakup total 17.717 pelayanan dan 2.366 unit layanan. Dua kementerian yang beroleh predikat kepatuhan tinggi antara lain Kementerian Luar Negeri dan Kementerian Agama. Sedangkan zona kuning atau tingkat kepatuhan sedang ditempati oleh Kementerian Agraria dan Tata Ruang serta Kementerian Sosial. Tiga lembaga yang dinilai yakni Badan Pengkajian dan Penerapan Teknologi (BPPT), Kepolisian Republik Indonesia dan Badan Nasional Sertifikasi Profesi (BNSP) ada di zona kuning atau tingkat kepatuhan sedang. Masih banyak pemerintah daerah tingkat kepatuhannya rendah. Kendati begitu Ombudsman enggan merinci detail pemda yang mendapat rapor merah tersebut. Ketua Ombudsman Amzulian Rifai hanya mengatakan beberapa pemda belum memiliki standar pelayanan publik yang baik. Dari beberapa artikel di atas, dapat disimpulkan bahwa sebagian besar pelayanan publik di Indonesia belum memenuhi harapan masyarakat artinya belum berkualitas, sehingga masih membutuhkan perbaikan kualitas agar mendapatkan rapor hijau.

Menurut Antony, Snee, et al. (2017), Quality improvement (QI) bukan hanya dilakukan dalam industri manufaktur, juga industri jasa maupun pelayanan publik. Pengembangan QI yang efektif atau Continuous improvement $(\mathrm{Cl})$ adalah faktor kunci untuk keberhasilan jangka panjang organisasi modern. Selama dekade terakhir, Lean Six Sigma (LSS) telah menjadi salah satu metodologi perbaikan proses bisnis yang paling populer dan terbukti. Lean Six Sigma merupakan suatu pendekatan yang fokus pada memperbaiki kualitas, mengurangi variasi, dan menghilangkan waste dalam suatu organisasi (Furterer, 2009). Lean Six Sigma merupakan kombinasi dari dua program perbaikan yaitu Six Sigma dan Lean enterprise.

Beberapa manfaat menggunakan LSS dalam organisasi sektor publik yaitu (1) biaya yang terkait dengan upaya penyelesaian masalah yang salah arah (tidak menggunakan metodologi terstruktur) dapat dikurangi secara signifikan, (2) meningkatkan pemahaman tentang Voice of Customer (VOC) dan Critical to Quality (CTQ) akan memiliki dampak terbesar pada kepuasan pelanggan, (3) dapat mengurangi jumlah operasi yang tidak bernilai tambah melalui eliminasi secara sistematis, mengarah ke pengiriman layanan yang lebih cepat, waktu tunggu yang lebih cepat, waktu siklus yang lebih cepat, (4) Transformasi budaya organisasi dari pola pikir reaktif menjadi proaktif, (5) Banyak manajer tidak memiliki pengetahuan 
statistik dan kemampuan untuk menerapkan statistik penyelesaian masalah. LSS menyediakan kerangka kerja mendasar bagi para manajer dalam menggunakan alat dan teknik statistik terapan untuk pemecahan masalah di sektor publik, (6) Responsif dan fleksibilitas yang lebih besar untuk memenuhi kebutuhan pelanggan (Antony, Snee, et al., 2017)

Berdasarkan beberapa penelitian sebelumnya mengenai penerapan Lean Six Sigma pada sektor publik, terlihat beberapa bidang yang sudah diteliti yaitu: bidang Kesehatan (Antony et al., 2016; Antony, Rodgers, et al., 2017; Panuti et al., 2013; Rodgers \& Antony, 2019), bidang Peradilan pidana (Antony et al., 2016), bidang Pendidikan, bidang Pemerintah Daerah (Antony et al., 2016; Antony, Rodgers, et al., 2017; Rodgers \& Antony, 2019), bidang Pemerintah Pusat (Rodgers \& Antony, 2019), bidang Pemerintahan Kota (Fletcher, 2018), bidang Layanan Kepolisian (Antony, Rodgers et al., 2017), dan bidang sektor publik lainnya yang tidak dijelaskan secara spesifik (Rodgers \& Antony, 2019). Dari penelitianpenelitian di atas, diketahui bahwa ada usaha dari beberapa peneliti untuk membuktikan keberhasilan penerapan Lean Six Sigma pada sektor publik, namun bidang-bidang penerapannya masih terbatas dan belum spesifik. Selama ini penerapan Lean Six Sigma sudah dilaksanakan secara luas pada bidang manufaktur dan jasa (Antony, Rodgers, et al., 2017; Sunder et al., 2019).

Penelitian ini dilakukan pada unit pelayanan verifikasi dan kalibrasi alat ukur yang ada di lingkungan Kementerian Perdagangan. Berdasarkan data kinerja pelayanan dan data pengaduan pelanggan tahun 2018 serta pengamatan di lapangan diindikasikan bahwa kinerja layanan belum memenuhi sasaran mutu (target $85 \%$ ) dan adanya waste pada jenis keluhan pelanggan. Berdasarkan ulasan mengenai pentingnya kualitas pelayanan publik, Lean Six Sigma, dan kasus yang dihadapi di atas, dengan demikian terdapat gap yang dapat diisi oleh penulis yaitu penelitian mengenai Lean Six Sigma pada pelayanan publik khususnya pada bidang pelayanan verifikasi standar ukuran dan kalibrasi alat ukur metrologi teknis. Penelitian ini bertujuan untuk mengetahui penyebab keterlambatan waktu dan pemborosan yang terjadi pada pelayanan verifikasi/kalibrasi. Hasil perbaikan diharapkan mampu meningkatkan kualitas pelayanan verifikasi standar ukuran dan kalibrasi alat ukur metrologi teknis.

\section{METODE PENELITIAN}

Penelitian ini menggunakan metodologi Lean Six Sigma yang terdiri dari 5 fase yaitu Define, Measure, Analyze, Improve, dan Control (DMAIC).
Metodologi DMAIC paling efektif untuk implementasi LSS guna perbaikan proses dalam konteks organisasi (Sunder et al., 2019). LSS DMAIC adalah metodologi yang paling berhasil untuk perbaikan proses di sektor jasa (Hayler \& Nichols, 2006; Rucker, 2000; Sunder, 2016).

\section{Fase Define}

Fase ini bertujuan untuk menggambarkan masalah dan ruang lingkup proyek dan proses yang harus ditingkatkan (Furterer, 2009). Tools yang digunakan dalam fase ini yaitu Project Charter dan SIPOC. Dalam Project Charter akan terlihat gambaran proyek secara umum. Selanjutnya pembuatan tabel Suppliers, Inputs, Process, Outputs, dan Customers (SIPOC) untuk menggambarkan proses dan subproses apa saja dalam pelayanan verifikasi/ kalibrasi tersebut sehingga fokus proyek dapat ditentukan pada proses atau sub proses apa saja.

\section{Fase Measure}

Fase ini bertujuan untuk memahami dan mendokumentasikan keadaan saat ini dari proses yang akan ditingkatkan, dalam hal ini keadaan yang berhubungan dengan Critical to Satisfaction (ada dalam project charter). Dilakukan perhitungan level sigma untuk kinerja laboratorium tahun 2018 (karena kinerja laboratorium merupakan bagian dari kinerja pelayanan) untuk melihat kapabilitas proses sebelum perbaikan. Selanjutnya pembuatan current Value Stream Mapping (VSM) tahun 2018 sehubungan adanya indikasi waste pada pengaduan pelanggan.

\section{Fase Analyze}

Fase ini bertujuan untuk menganalisis data yang ada pada fase measure, mengidentifikasi pemborosan-pemborosan yang ada berdasarkan VSM, mengidentifikasi penyebab yang berhubungan dengan CTS menggunakan diagram Fishbone, dan merekapitulasi semua penyebab dan pemborosan menggunakan Failure Mode and Effect Analysis (FMEA). Analisis Value Stream dapat membantu menemukan waste yang tersembunyi dalam suatu organisasi (Munro et al., 2015). Analisis ini diwujudkan dalam identifikasi pemborosan. Fishbone diagram merupakan alat analisis grafis yang memungkinkan pengguna untuk menampilkan faktor-faktor yang terlibat dalam situasi tertentu. Diagram ini untuk menggambarkan dengan jelas berbagai penyebab $(\mathrm{x})$ yang mempengaruhi item yang sedang diselidiki (Munro et al., 2015) dan dapat menggambarkan rantai sebab-akibat guna membantu analisis akar penyebab (Mättö, 2019). FMEA digambarkan sebagai kelompok aktivitas 
sistemik yang dimaksudkan untuk (1) Mengenali dan mengevaluasi potensi kegagalan dan efek dari kegagalan itu, (2) Identifikasi tindakan yang dapat menghilangkan atau mengurangi kemungkinan terjadinya potensi kegagalan terjadi dan (3) dokumentasikan seluruh proses (El-Haik \& Yang, 2003).

\section{Fase Improve}

Fase ini bertujuan untuk mengidentifikasi rekapitulasi usulan perbaikan, mengimplementasikan dan kemudian menilai peningkatannya. Tools yang digunakan yaitu brainstorming bersama pihak-pihak terkait, perhitungan level sigma setelah perbaikan, dan uji hipotesis

\section{Fase Control}

Fase ini bertujuan untuk merancang, mengembangkan, dan menggabungkan kontrol ke dalam proses yang diperbaiki. Tools yang digunakan yaitu Control Plan dan Future VSM

\section{HASIL DAN PEMBAHASAN Fase Define}

Langkah awal fase define ini yaitu dengan membuat project charter (Tabel 1) dan SIPOC (Tabel 2) Project charter membantu tim untuk fokus pada tujuan proyek dan memperjelas peran dan tanggung jawab masing-masing anggota tim (Trakulsunti et al., 2020)

\section{Tabel 1. Project Charter}

\begin{tabular}{|c|c|}
\hline $\begin{array}{l}\text { Project } \\
\text { Name }\end{array}$ & $\begin{array}{l}\text { Perbaikan Proses Pelayanan Verifikasi Standar Ukuran dan } \\
\text { Kalibrasi Alat Ukur Metrologi Teknis pada Balai SNSU (dalam } \\
\text { penelitian ini digunakan istilah pelayanan verifikasi/ kalibrasi). }\end{array}$ \\
\hline $\begin{array}{l}\text { Problem } \\
\text { Statement }\end{array}$ & $\begin{array}{l}\text { Pelayanan Verifikasi/Kalibrasi Alat Ukur masih belum } \\
\text { memenuhi sasaran mutu yang ada (waktu pelayanan non } \\
\text { perizinan yang sesuai standar waktu pelayanan kurang dari } \\
85 \% \text { ), level sigma yang dimiliki kurang dari } 6 \text {, dan masih ada } \\
\text { keluhan pelanggan. }\end{array}$ \\
\hline $\begin{array}{l}\text { Customer/ } \\
\text { Stakeholder }\end{array}$ & $\begin{array}{l}\text { Primary stakeholder terdiri dari: Direktur Metrologi, Kepala Balai } \\
\text { SNSU, Intern SNSU, Frontliner UPTP IV, Pemilik Standard/ alat } \\
\text { ukur (termasuk Unit Metrologi Legal). Secondary stakeholder } \\
\text { terdiri dari Komite Akreditasi Nasional, dan Lembaga Sertifikasi } \\
\text { ISO } 9001 \text {. }\end{array}$ \\
\hline $\begin{array}{l}\text { What is } \\
\text { important to } \\
\text { these } \\
\text { customers - } \\
\text { CTS }\end{array}$ & $\begin{array}{l}\text { a. Minimasi keterlambatan waktu pelayanan verifikasi/ kalibrasi } \\
\text { Berdasarkan data kinerja pelayanan verifikasi/ kalibrasi di } \\
\text { Balai SNSU tahun } 2018 \text {, suatu order dikatakan tepat waktu } \\
\text { jika order tersebut selesai (Standar ukuran/ alat ukur sudah } \\
\text { diuji, dan sertifikat sudah siap) maksimal } 10 \text { hari dari tanggal } \\
\text { kwitansi. } \\
\text { b. Minimasi kesalahan penulisan pada sertifikat }\end{array}$ \\
\hline $\begin{array}{l}\text { Goal of the } \\
\text { project }\end{array}$ & $\begin{array}{l}\text { Menganalisis proses Pelayanan Verifikasi/ Kalibrasi } \\
\text { menggunakan metodologi Lean Six Sigma dengan tahapan } \\
\text { DMAIC sehingga diharapkan akan diperoleh usulan perbaikan }\end{array}$ \\
\hline $\begin{array}{l}\text { Scope } \\
\text { statement: }\end{array}$ & $\begin{array}{l}\text { Proyek ini akan menganalisis } \\
\text { - Proses pelayanan Verifikasi Standar Ukuran dan Kalibrasi } \\
\text { mulai dari tanggal masuk order sampai tanggal selesai order. } \\
\text { - Proses pelayanan yang diamati hanya proses yang } \\
\text { dilaksanakan di laboratorium Balai SNSU } \\
\text { - Proses teknis intern dalam menguji alat tidak dianalisis } \\
\text { karena metode pengujian berdasarkan aturan-aturan baku } \\
\text { berdasarkan OIML (International Organization of Legal } \\
\text { Metrology) dan syarat teknis yang disahkan oleh Menteri } \\
\text { Perdagangan Republik Indonesia sehingga dalam hal ini } \\
\text { penulis mengasumsikan metode pengujian sudah valid. } \\
\text { - Pengaturan pegawai (pranata laboratorium dan pembantu } \\
\text { teknis) antara di dalam laboratorium dengan luar } \\
\text { laboratorium diasumsikan sudah optimal } \\
\text { - Hanya } 1 \text { siklus DMAIC yang diamati } \\
\text { - Ada } 2 \text { CTS yang diperhatikan dalam proyek ini } \\
\text { Pola data jumlah sertifikat dan item kalibrasi untuk tahun } \\
2020 \text { diasumsikan mirip dengan tahun } 2019 \\
\text { - Target kinerja laboratorium diasumsikan } 85 \%\end{array}$ \\
\hline
\end{tabular}

Tabel 2. SIPOC

\begin{tabular}{|c|c|c|c|c|}
\hline Supplier & Input & Process & Outputs & Customer \\
\hline Pelanggan & $\begin{array}{l}\text { - Surat } \\
\text { permohonan } \\
\text { - Standar } \\
\text { Ukur/ Alat } \\
\text { ukur } \\
\text { - Formulir } \\
\text { pendaftaran } \\
\text { - Sertifikat } \\
\text { lama (jika } \\
\text { ada) } \\
\end{array}$ & $\begin{array}{l}\text { Penerimaan } \\
\text { berkas } \\
\text { permohonan }\end{array}$ & $\begin{array}{l}\text { - Kwitansi } \\
\text { - Map } \\
\text { order }\end{array}$ & $\begin{array}{l}\text { Pelanggan } \\
\text { Lab } \\
\text { SNSU }\end{array}$ \\
\hline $\begin{array}{l}\text { Frontliner } \\
\text { UPTP IV }\end{array}$ & $\begin{array}{l}\text { - Map order } \\
\text { - Alat/standar }\end{array}$ & $\begin{array}{l}\text { Verifikasi } \\
\text { atau } \\
\text { Kalibrasi }\end{array}$ & $\begin{array}{l}\text { - Standar } \\
\text { ukur/ Alat } \\
\text { ukur yang } \\
\text { sudah } \\
\text { ditandai } \\
\text { - Cerapan } \\
\end{array}$ & $\begin{array}{l}\text { Frontliner } \\
\text { UPTP IV }\end{array}$ \\
\hline $\begin{array}{l}\text { Laborato- } \\
\text { rium } \\
\text { SNSU }\end{array}$ & - Cerapan & $\begin{array}{l}\text { Pembuatan } \\
\text { sertifikat }\end{array}$ & $\begin{array}{l}\text { - Sertifik } \\
\text { at }\end{array}$ & $\begin{array}{l}\text { Frontliner } \\
\text { UPTP IV }\end{array}$ \\
\hline $\begin{array}{l}\text { Laborato- } \\
\text { rium } \\
\text { SNSU }\end{array}$ & $\begin{array}{l}\text { - Standar } \\
\text { ukur/ Alat } \\
\text { Ukur yang } \\
\text { sudah } \\
\text { ditandai } \\
\text { - Sertifikat } \\
\end{array}$ & $\begin{array}{l}\text { Penyampaian- } \\
\text { produk } \\
\text { layanan }\end{array}$ & $\begin{array}{l}\text { 1- Standar } \\
\text { ukur/ Alat } \\
\text { ukur yang } \\
\text { sudah } \\
\text { ditandai } \\
\text { - Sertifikat }\end{array}$ & Konsumen \\
\hline
\end{tabular}

Berkaitan dengan CTS yang disebutkan pada Project Charter (Tabel 1) maka proses yang akan menjadi fokus dalam penelitian adalah proses penerimaan berkas permohonan sampai pembuatan sertifikat (Tabel 2).

\section{Fase Measure}

Untuk mengidentifikasi pemborosan, maka digunakan current VSM (Gambar 1). Dalam VSM terlihat jalannya proses yang akan dilalui oleh standar ukuran/ alat ukur yaitu 4 proses utama. proses pertama yaitu penerimaan berkas permohonan (bagian penerimaan barang ada 3 aktivitas, bagian kasir ada 1 aktivitas, dan bagian delivery barang ada 1 aktivitas). Proses kedua yaitu verifikasi/kalibrasi (laboratorium G\&T, Suhu, Massa, Listrik, Panjang, dan Volume, dimana masing-masing laboratorium memiliki 4 aktivitas). Proses ketiga yaitu proses pembuatan sertifikat ada 5 aktivitas (Tata Usaha, Kabalai SNSU, Kasie Pelayanan Teknis dan laboratorium). Proses keempat adalah proses penyampaian produk layanan yang terdiri dari 5 aktivitas (bagian pengambilan barang). Aliran informasi sebagian besar masih dilakukan secara manual, terutama aktivitas yang mempunyai aktivitas bolak balik. Hal ini berdampak pada proses penyelesaian order tidak sesuai dengan yang telah ditetapkan. Target total waktu penyelesaian 1 order maksimal 11 hari setelah tanggal kwitansi. Berdasarkan permasalahan yang sering terjadi, penelitian ini berfokus pada 2 proses utama yaitu proses pada laboratorium dan proses di Tata Usaha. Target penyelesaian order pada kedua proses ini adalah selama 10 hari dengan rincian 7 hari di di laboratorium (6 aktivitas jenis pengujian) dan 3 hari di Tata Usaha yang berhubungan dengan penerbitan sertifikat. 


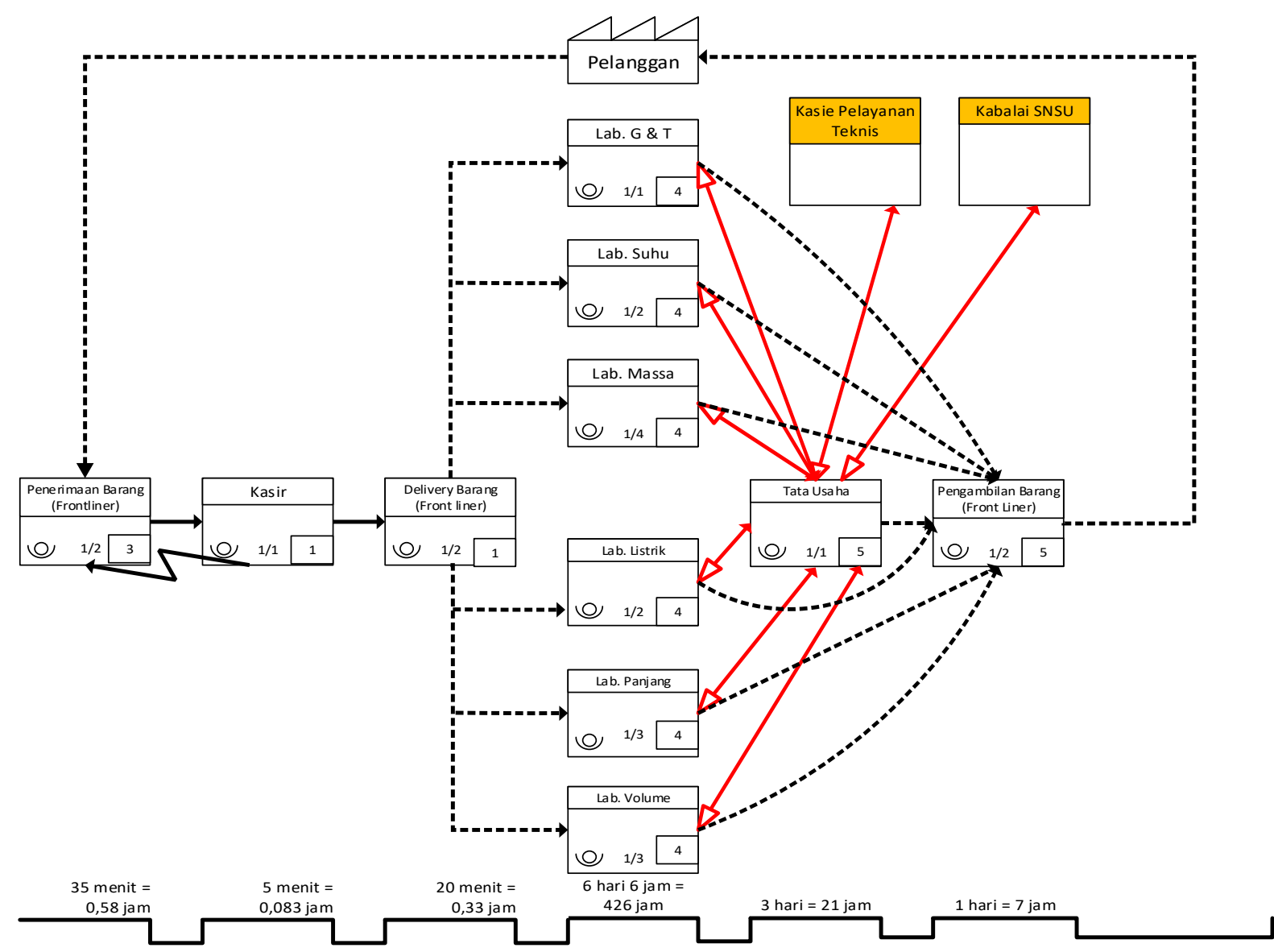

Gambar 1. Current VSM

Langkah selanjutnya adalah melakukan Selanjutnya perhitungan Level Sigma dari Kinerja Laboratorium Tahun 2018 (Tabel 3). Level sigma dari kinerja laboratorium berkisar dari $0,31-2,2$ dengan rata-rata $1,43(527.900$ PPM) dengan terendah di bulan desember $(0,31)$ dan tertinggi di bulan Juni $(2,2) \mathrm{Hal}$ ini belum mencapai level sigma 6 (3,4 PPM).

Tabel 3. Perhitungan Level Sigma dari Kinerja Laboratorium Tahun 2018

\begin{tabular}{|c|c|c|c|c|c|c|c|c|}
\hline Bulan & $\begin{array}{c}\text { Jumlah } \\
\text { Cacat }\end{array}$ & $\begin{array}{r}\text { Jml tidak } \\
\text { Cacat } \\
\end{array}$ & $\begin{array}{c}\text { Jumlah } \\
\text { sertifikat }\end{array}$ & $\begin{array}{c}p \text { (cacat) } \\
{[2] /[4]}\end{array}$ & $\begin{array}{c}\text { p (tidak cacat) } \\
1-[5]\end{array}$ & $\begin{array}{c}\text { PPM } \\
{[5] x} \\
1000000\end{array}$ & $\begin{array}{c}\text { Level Sig } \\
\text { NORM.S.INV } \\
\text { [6] }\end{array}$ & $\begin{array}{l}\text { na } \\
{[8]+1,5}\end{array}$ \\
\hline [1] & [2] & [3] & [4] & [5] & {$[6]$} & [7] & [8] & [9] \\
\hline Jan & 232 & 312 & 544 & 0,426471 & 0,57353 & 426.471 & 0,19 & 1,69 \\
\hline Feb & 155 & 159 & 314 & 0,493631 & 0,50637 & 493.631 & 0,02 & 1,52 \\
\hline Mar & 198 & 219 & 417 & 0,474820 & 0,52518 & 474.820 & 0,06 & 1,56 \\
\hline Apr & 114 & 205 & 319 & 0,357367 & 0,64263 & 357.367 & 0,37 & 1,87 \\
\hline Mei & 216 & 176 & 392 & 0,551020 & 0,44898 & 551.020 & $-0,13$ & 1,37 \\
\hline Juni & 39 & 123 & 162 & 0,240741 & 0,75926 & 240.741 & 0,70 & 2,20 \\
\hline Juli & 112 & 270 & 382 & 0,293194 & 0,70681 & 293.194 & 0,54 & 2,04 \\
\hline Agt & 366 & 199 & 565 & 0,647788 & 0,35221 & 647.788 & $-0,38$ & 1,12 \\
\hline Sept & 482 & 213 & 695 & 0,693525 & 0,30647 & 693.525 & $-0,51$ & 0,99 \\
\hline Okt & 198 & 230 & 428 & 0,462617 & 0,53738 & 462.617 & 0,09 & 1,59 \\
\hline Nov & 363 & 145 & 508 & 0,714567 & 0,28543 & 714.567 & $-0,57$ & 0,93 \\
\hline Des & 442 & 59 & 501 & 0,882236 & 0,11776 & 882.236 & $-1,19$ & 0,31 \\
\hline Total & 2917 & 2310 & 5227 & & & & & \\
\hline Rata-rata & 243 & 193 & 436 & & & & & 1,43 \\
\hline & $\begin{array}{l}\text { Jumla } \\
\text { Jumla } \\
\text { PPM }\end{array}$ & cat & $\begin{array}{l}=\text { jumlant terlam } \\
=\text { jumlah tepat } \\
=\text { part per millio }\end{array}$ & $\begin{array}{l}\text { + jumlah belun } \\
\text { tu (dalam unit) } \\
\text { efective }\end{array}$ & & at) & $\begin{array}{l}=\text { peluang cacat } \\
=\text { peluang tidak caca }\end{array}$ & \\
\hline
\end{tabular}




\section{Fase Analyze}

Berdasarkan current VSM (Gambar 1) maka aktivitas-aktivitas dipilah-pilah lagi untuk mengidentifikasi pemborosan (Tabel 4) sehingga ditemukan 12 waste ( 9 motion, 3 waiting) yang

termasuk type two waste dan ada 3 non value added yang termasuk type one waste (2 excess processing, 1 transportation).

Tabel 4. Identifikasi Pemborosan

\begin{tabular}{|c|c|c|c|c|c|c|}
\hline \multirow{2}{*}{ No } & \multicolumn{3}{|c|}{ Aktivitas } & \multicolumn{3}{|c|}{ Tipe Aktivitas } \\
\hline & Input & Aktivitas & Output & Value added & Non Value added & Waste \\
\hline \multicolumn{7}{|c|}{ Penerimaan Barang (Front Liner) } \\
\hline 1 & $\begin{array}{l}\text { Formulir } \\
\text { pendaftaran }\end{array}$ & $\begin{array}{l}\text { Pengisian formulir pendaftaran oleh } \\
\text { pelanggan (tulis tangan) }\end{array}$ & $\begin{array}{l}\text { Formulir } \\
\text { pendaftaran } \\
\text { yang sudah diisi }\end{array}$ & & & Motion \\
\hline 2 & $\begin{array}{l}\text { - Surat permohonan } \\
\text { - formulir pendaftaran } \\
\text { yang sudah diisi } \\
\text { - Standar Ukuran/ Alat } \\
\text { Ukur } \\
\text { - Sertifikat lama (jika } \\
\text { ada) }\end{array}$ & $\begin{array}{l}\text { Verifikasi berkas dan Standar Ukuran/ Alat } \\
\text { Ukur }\end{array}$ & $\begin{array}{l}\text { Formulir } \\
\text { pendaftaran } \\
\text { yang sudah di } \\
\text { checklist }\end{array}$ & V & & \\
\hline 3 & $\begin{array}{l}\text { Formulir pendaftaran } \\
\text { yang sudah di } \\
\text { checklist }\end{array}$ & $\begin{array}{l}\text { Input data } \\
\text { - identitas pemohon } \\
\text { - identitas pemilik } \\
\text { - identitas alat }\end{array}$ & Invoice & & & $\begin{array}{l}\text { Waiting } \\
\text { Waiting } \\
\text { Waiting }\end{array}$ \\
\hline 4 & $\begin{array}{l}\text { Kwitansi dari kasir (on } \\
\text { line) }\end{array}$ & Print kelengkapan map order & Map order & V & & \\
\hline 5 & Label & Pelabelan UTTP/Standar & $\begin{array}{l}\text { UTTP/ } \text { standar } \\
\text { yang sudah } \\
\text { diberi label }\end{array}$ & V & & \\
\hline \multicolumn{7}{|c|}{ Kasir } \\
\hline 6 & $\begin{array}{ll}- & \text { Invoice } \\
\text { - } & \text { Uang/transfer }\end{array}$ & $\begin{array}{l}\text { Input data invoice dan menerbitkan } \\
\text { kwitansi }\end{array}$ & kwitansi & $\mathrm{V}$ & & \\
\hline \multicolumn{7}{|c|}{ Delivery Barang (Front Liner) } \\
\hline 7 & $\begin{array}{l}\text { - Formulir } \\
\text { pendaftaran } \\
\text { - Standar Ukuran/ } \\
\text { Alat Ukur }\end{array}$ & Input data Standar Ukuran/ Alat Ukur & $\begin{array}{lr}\text { Buku } & \text { serah } \\
\text { terima } & \text { Standar } \\
\text { Ukuran/Alat Ukur }\end{array}$ & & & Motion \\
\hline 8 & $\begin{array}{l}\text { - Handtruck } \\
\text { - Standar Ukuran/ } \\
\text { Alat Ukur }\end{array}$ & $\begin{array}{l}\text { Delivery Standar Ukuran/ Alat Ukur ke } \\
\text { laboratorium }\end{array}$ & $\begin{array}{l}\text { Standar Ukuran/ } \\
\text { Alat Ukur sudah } \\
\text { ada }\end{array}$ & V & & \\
\hline 9 & $\begin{array}{l}\text { Buku serah terima } \\
\text { Standar Ukuran/ Alat } \\
\text { Ukur }\end{array}$ & Serah terima barang & $\begin{array}{l}\text { Buku sudah } \\
\text { ditandatangani }\end{array}$ & V & & \\
\hline \multicolumn{7}{|c|}{ Lab.G\&T, Suhu, Massa, Listrik, Panjang, Volume } \\
\hline 10 & $\begin{array}{l}\text { Standar Ukuran/ Alat } \\
\text { Ukur }\end{array}$ & $\begin{array}{l}\text { Pengkondisian } \\
\text { Standar Ukuran/ Alat Ukur }\end{array}$ & $\begin{array}{l}\text { Standar Ukuran/ } \\
\text { Alat Ukur yang } \\
\text { siap untuk diuji }\end{array}$ & $\mathrm{V}$ & & \\
\hline 11 & $\begin{array}{l}\text { Standar Ukuran/ Alat } \\
\text { Ukur yang siap diuji }\end{array}$ & Pengujian & $\begin{array}{l}\text { Data hasil } \\
\text { pengujian }\end{array}$ & V & & \\
\hline 12 & Data hasil pengujian & $\begin{array}{l}\text { Pengolahan data } \\
\text { - Input manual identifikasi alat } \\
\text { - Input manual data hasil pengujian } \\
\text { - Input manual nomor order }\end{array}$ & Cerapan & V & & $\begin{array}{l}\text { Motion } \\
\text { Motion }\end{array}$ \\
\hline 13 & $\begin{array}{l}\text { Label selesai } \\
\text { pengujian }\end{array}$ & $\begin{array}{l}\text { Pelabelan Standar Ukuran/ Alat Ukur hasil } \\
\text { pengujian }\end{array}$ & $\begin{array}{l}\text { Standar Ukuran/ } \\
\text { Alat Ukur sudah } \\
\text { diberi label }\end{array}$ & V & & \\
\hline \multicolumn{7}{|c|}{ Tata Usaha } \\
\hline 14 & $\begin{array}{l}\text { - } \text { Cerapan } \\
\text { - Formulir } \\
\text { pendaftaran } \\
\text { - Surat permohonan }\end{array}$ & $\begin{array}{l}\text { Membuat konsep sertifikat } \\
\text { - Input manual identitas pemohon } \\
\text { - Input manual identitas pemilik sertifikat } \\
\text { - Input manual identitas alat } \\
\text { - Input manual no order } \\
\text { - Input manual data dari cerapan }\end{array}$ & Konsep sertifikat & & & $\begin{array}{l}\text { Motion } \\
\text { Moton } \\
\text { Motion } \\
\text { Motion } \\
\text { Motion }\end{array}$ \\
\hline 15 & Konsep sertifikat & $\begin{array}{l}\text { Verifikasi konsep sertifikat } \\
\text { - Verifikasi oleh masing-masing } \\
\text { laboratorium } \\
\text { - Verifikasi oleh Kasie Pelayanan Teknis }\end{array}$ & $\begin{array}{l}\text { Konsep sertifikat } \\
\text { yang sudah } \\
\text { diverifikasi }\end{array}$ & & $\begin{array}{l}\text { - Excess } \\
\text { processing, } \\
\text { Transportation } \\
\text { - Excess processing }\end{array}$ & \\
\hline 16 & $\begin{array}{l}\text { Konsep sertifikat } \\
\text { yang diverifikasi }\end{array}$ & Pencetakan sertifikat & Sertifikat & $\mathrm{V}$ & & \\
\hline 17 & Sertifikat & Penandatanganan sertifikat oleh Kabalai & $\begin{array}{l}\text { Sertifikat yang } \\
\text { sudah ditanda- } \\
\text { tangani }\end{array}$ & V & & \\
\hline 18 & $\begin{array}{lr}\text { Sertifikat } & \text { yang } \\
\text { sudah } & \text { ditanda- } \\
\text { tangani }\end{array}$ & Penomoran sertifikat & $\begin{array}{l}\text { Sertifikat yang } \\
\text { sudah selesai }\end{array}$ & $\mathrm{V}$ & & \\
\hline
\end{tabular}


Identifikasi penyebab yang berhubungan dengan CTS menggunakan Diagram Fishbone (Gambar 2 dan Gambar 3). Diagram ini dibuat dengan menganalisis database kinerja pelayanan tahun 2018, data pengaduan pelanggan tahun 2018 dan 2019, data dan peraturan-peraturan terkait Unit Metrologi Legal, wawancara dengan pihak terkait, serta pengamatan di lapangan. Dari hasil analisis didapatkan ada 1 penyebab utama keterlambatan waktu pelayanan kalibrasi/ verifikasi (CTS 1) yaitu waktu penyelesaian order lebih dari yang dijanjikan, sedangkan penyebab utama kesalahan penulisan pada sertifikat (CTS 2) ada 2 yaitu pelanggan salah tulis formulir permohonan dan salah ketik di laboratorium dan tata usaha.

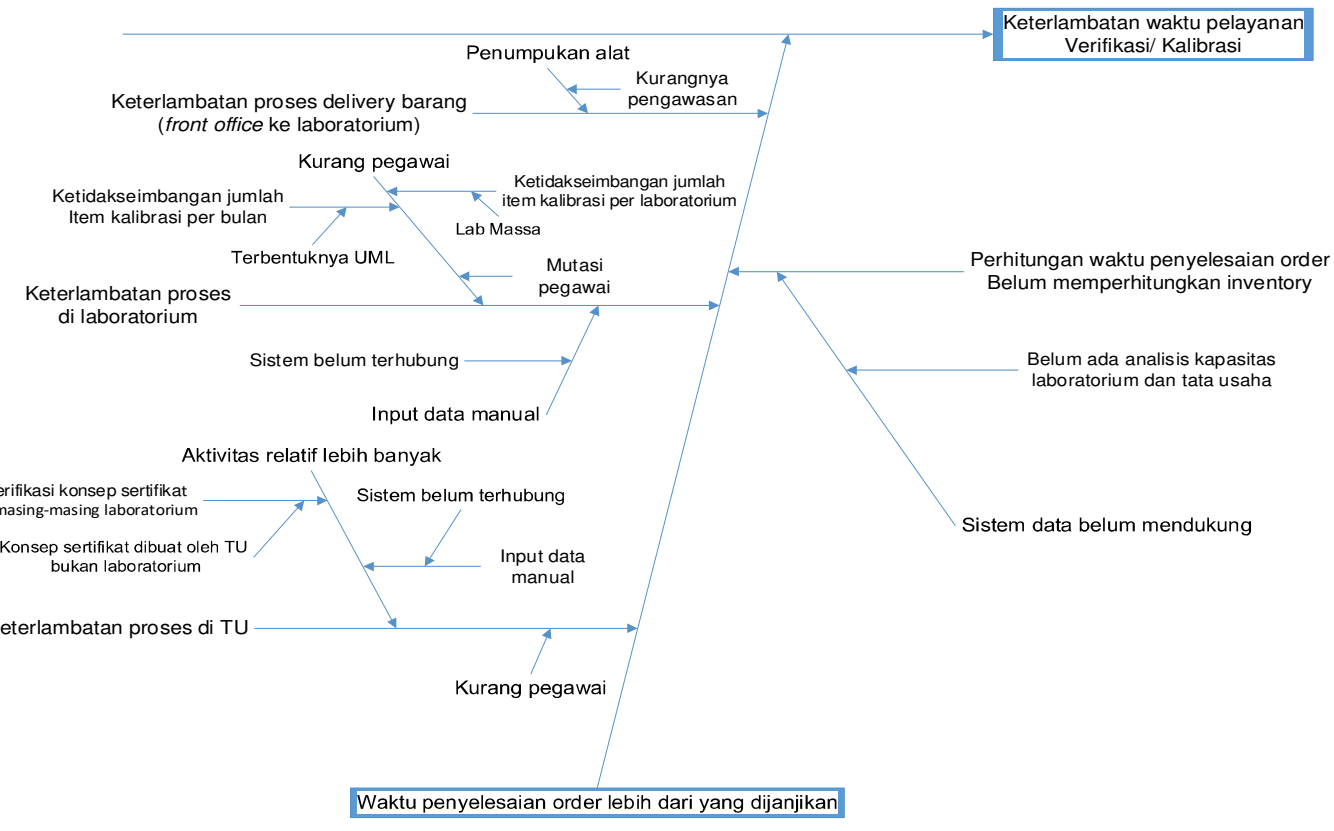

Gambar 2. Diagram Fishbone Keterlambatan Waktu Pelayanan Verifikasi/Kalibrasi

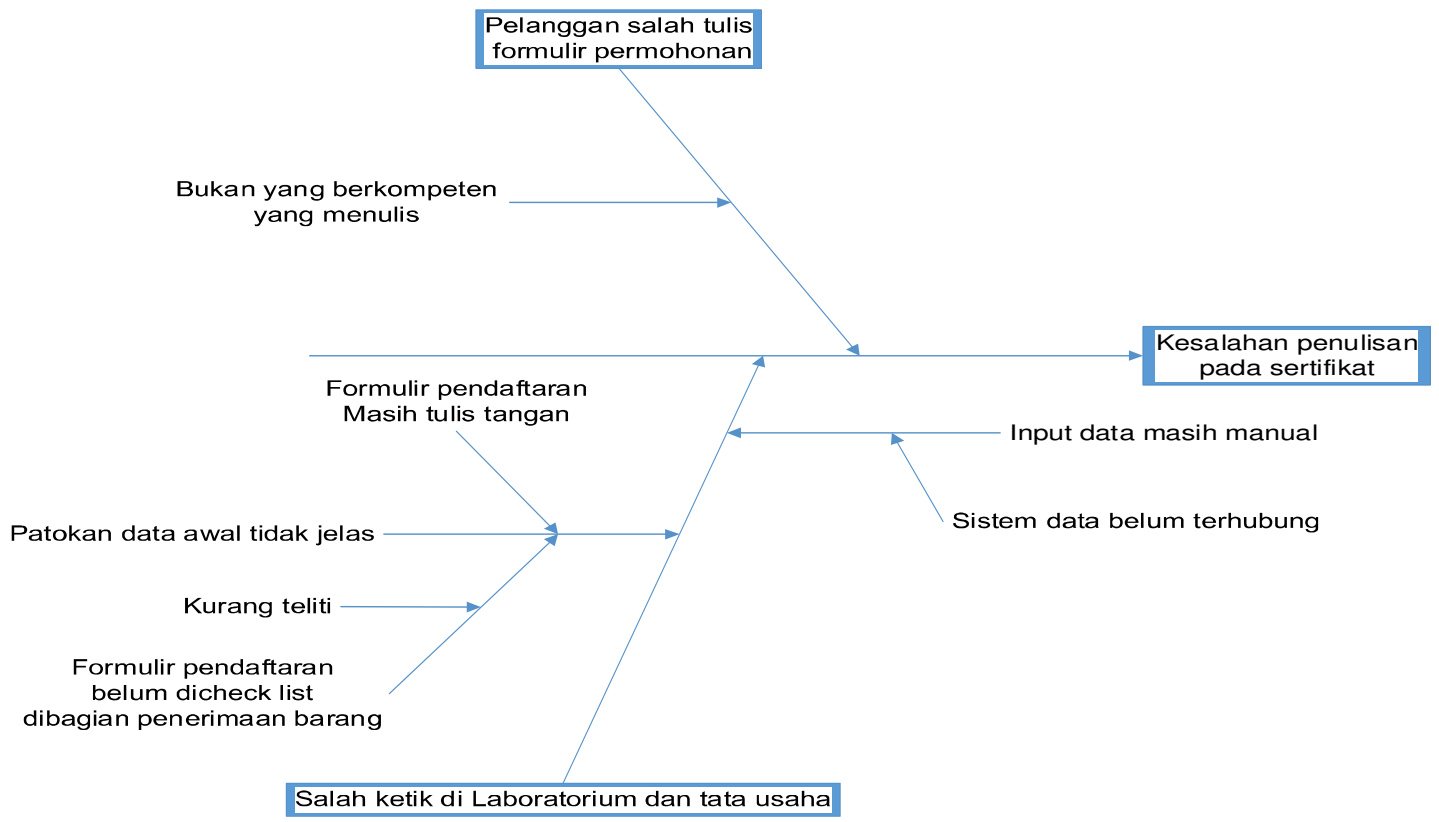

Gambar 3. Diagram Fishbone Kesalahan Penulisan pada Sertifikat 
TabeL 5. FMEA Sebelum diurutkan Berdasarkan RPN

\begin{tabular}{|c|c|c|c|c|c|c|c|c|c|c|}
\hline No & Proses & $\begin{array}{c}\text { Mode Kegagalan } \\
\text { Potensial }\end{array}$ & $\begin{array}{l}\text { Akibat Potensial dari Mode } \\
\text { Kegagalan }\end{array}$ & $\begin{array}{c}\text { Penyebab Potensial dari } \\
\text { Kegagalan }\end{array}$ & $\begin{array}{r}\text { Keadaan Sek } \\
\text { Pengendalian yang Dilakukan } \\
\end{array}$ & arang & Sev & Det & $\begin{array}{l}\text { Risk Priority } \\
\text { Number (RPN) }\end{array}$ & Usulan Tindakan Perbaikan \\
\hline \multicolumn{11}{|c|}{ Penerimaan Barang (Front Liner) } \\
\hline 1 & $\begin{array}{l}\text { Pengisian formulir pendaftaran } \\
\text { oleh pelanggan (tulis tangan) }\end{array}$ & Salah tulis & Kesalahan penulisan pada sertifikat & $\begin{array}{l}\text { Yang menulis bukan orang yang } \\
\text { berkompeten (misal: supir) }\end{array}$ & $\begin{array}{l}\text { Menghimbau agar pemilik alat yang } \\
\text { menulis formulir pendaftaran }\end{array}$ & 8 & 8 & 9 & 576 & $\begin{array}{l}\text { Menyediakan form pendaftaran di website agar dapat di download oleh } \\
\text { pelanggan agar dapat diketik terlebih dahulu }\end{array}$ \\
\hline 2 & $\begin{array}{l}\text { Pengisian formulir pendaftaran } \\
\text { oleh pelanggan (tulis tangan) }\end{array}$ & $\begin{array}{l}\text { Pergerakan berlebih } \\
\text { (waste jenis motion) }\end{array}$ & $\begin{array}{c}\text { Kepuasan pelanggan dapat } \\
\text { menurun }\end{array}$ & $\begin{array}{l}\text { Formulir pendaftaran ditulis tangan } \\
\text { oleh pelanggan saat mendaftar }\end{array}$ & ( & 7 & 7 & 10 & 490 & $=$ No.1 \\
\hline 3 & $\begin{array}{l}\text { Verifikasi berkas dan Standar } \\
\text { Ukuran/ Alat Ukur }\end{array}$ & $\begin{array}{l}\text { Formulir pendaftaran } \\
\text { belum di check list }\end{array}$ & kesalahan penulisan pada sertifikat & Kurang teliti & $\begin{array}{l}\text { Menghimbau agar pegawai } \\
\text { melakukan checklist dan yakin } \\
\text { kebenaran data yang ditulis }\end{array}$ & 8 & 8 & 8 & 512 & $\begin{array}{l}\text { Melaksanakan sosialisasi kepada pegawai terkait (penerimaan barang, delivery } \\
\text { barang, laboratorium, dan tata usaha) mengenai pentingnya kebenaran data di } \\
\text { awal }\end{array}$ \\
\hline 4 & $\begin{array}{l}\text { Input data identitas pemohon, } \\
\text { identitas pemilik, dan identitas alat } \\
\text { (bagian penerimaan barang) }\end{array}$ & $\begin{array}{l}\text { Pelanggan menunggu } \\
\text { (waste jenis waiting) }\end{array}$ & $\begin{array}{l}\text { Kepuasan pelanggan dapat } \\
\text { menurun }\end{array}$ & $\begin{array}{l}\text { Pelanggan lupa menyertakan } \\
\text { sertifikat lama }\end{array}$ & $\begin{array}{l}\text { Menghimbau agar membawa } \\
\text { sertifikat lama }\end{array}$ & 7 & 7 & 9 & 441 & $\begin{array}{l}\text { Sosialisasi ke pelanggan agar membawa sertitikat lama pada saat pendaftaran } \\
\text { agar proses input dapat lebih cepat }\end{array}$ \\
\hline 5 & $\begin{array}{l}\text { Input data identitas pemohon, } \\
\text { identitas pemilik, dan identitas olat } \\
\text { (bagian penerimaan barang) }\end{array}$ & $\begin{array}{l}\text { Pelanggan menunggu } \\
\text { (waste jenis waiting) }\end{array}$ & $\begin{array}{l}\text { Kepuasan pelanggan dapat } \\
\text { menurun }\end{array}$ & $\begin{array}{l}\text { Kurangnya kecepatan pada } \\
\text { perangkat komputer yang ada }\end{array}$ & $\begin{array}{l}\text { Mengusulkan peningkatan } \\
\text { kecepatan dan kapasistas serangkat } \\
\text { komputer yang ada }\end{array}$ & 8 & 7 & 9 & 504 & Usul peningkatan kecepatan dan kapasitas perangkat komputer yang ada \\
\hline \multicolumn{11}{|c|}{ Delivery Barang (Front Liner) } \\
\hline 6 & Delivery barang & Terlambat & $\begin{array}{l}\text { Keterlambatan waktu pelayanan } \\
\text { kalibrasi/ verifikasi }\end{array}$ & $\begin{array}{l}\text { Penumpukan Alat Karena } \\
\text { Kurangnya Pengawasan }\end{array}$ & $\begin{array}{l}\text { Map order dan Standarl Alat masuk } \\
\text { laboratorium max } \mathrm{H}+1\end{array}$ & 9 & 9 & 10 & 810 & $\begin{array}{l}\text { 1. Pada tahun } 2019 \text { sudah dilaksanakan Map order dan Standar/alat masuk } \\
\text { 2. Maboratorium max H+1 } \\
\text { Membuat sistem yang dapat memberi alarm }\end{array}$ \\
\hline 7 & $\begin{array}{l}\text { Input data Standar Ukuran/ Alat } \\
\text { ukur }\end{array}$ & $\begin{array}{l}\text { Pergerakan berlebih } \\
\text { (waste jenis motion) }\end{array}$ & Pekerjaan tidak efisien & $\begin{array}{l}\text { Data dalam sistem penerimaan } \\
\text { barang belum terhubung dengan } \\
\text { bagian delivery barang }\end{array}$ & - & 8 & 7 & 10 & 560 & $\begin{array}{l}\text { Bagian penerimaan barang menerbitkan form yang berisi data-data yang } \\
\text { dibutuhkan saat serah terima barang }\end{array}$ \\
\hline \multicolumn{11}{|c|}{ Laboratorium G\&T, Suhu, Massa, Listrik, Panjang, Volume } \\
\hline 8 & $\begin{array}{l}\text { Proses di laboratorium: } \\
\text { - Pengkondisian } \\
\text { : Pengujian } \\
\text { - Pengolahan nata } \\
\text { - Pelabelan standar }\end{array}$ & Terlambat & $\begin{array}{l}\text { Keterlambatan waktu pelayanan } \\
\text { kalibrasi/ verifikasi }\end{array}$ & Kurang pegawai karena mutasi & Mengajukan penambahan pegawai & 10 & 9 & 10 & 900 & Tahun 2019 sudah ada penambahan 1 pegawai di Laboratorium Panjang \\
\hline 9 & $\begin{array}{l}\text { Proses di laboratorium: } \\
\text { - Pengkononidian } \\
\text { - Penguian } \\
\text { - Pengolahanan data } \\
\text { - Pelabelan standar }\end{array}$ & Terlambat & $\begin{array}{l}\text { Keterlambatan waktu pelayanan } \\
\text { kalibrasi verifikasi }\end{array}$ & $\begin{array}{l}\text { Kurang pegawai karena } \\
\text { ketidakseimbangan item kalibrasi } \\
\text { per laboratorium terutama dari } \\
\text { Laboratorium Massa }\end{array}$ & $\begin{array}{l}\text { Pegawai dari laboratorium lain ikut } \\
\text { membantu di laboratorium massa }\end{array}$ & 10 & 9 & 9 & 810 & Mengajukan penambahan pegawai \\
\hline 10 & $\begin{array}{l}\text { Proses di laboratorium: } \\
\text { - Pengkononisian } \\
\text { - Pengujian } \\
\text { - Pengolahan data } \\
\text { Pelabelan standar }\end{array}$ & Terlambat & $\begin{array}{l}\text { Keterlambatan waktu pelayanan } \\
\text { kalibrasi verifikasi }\end{array}$ & $\begin{array}{l}\text { Kurang pegawai disebabkan oleh } \\
\text { ketidakseimbangan item kalibrasi } \\
\text { per bulan disebabkan } \\
\text { terbentuknya UML }\end{array}$ & - & 10 & 9 & 10 & 900 & $\begin{array}{l}\text { Menghimbau kepada pelanggan swasta agar mengkalibrasikan alatnya di awal } \\
\text { tahun (Januari - Juli) }\end{array}$ \\
\hline 11 & $\begin{array}{l}\text { Pengolahan data: } \\
\text { Input manual data identififikasi } \\
\text { alat mit } \\
\text { Input data hasil pengujian } \\
\text { Input manual no order }\end{array}$ & Terlambat & $\begin{array}{l}\text { Keterlambatan waktu pelayanan } \\
\text { kalibrasi/ verifikasi }\end{array}$ & $\begin{array}{l}\text { Input data yang masih manual } \\
\text { karena sistem belum terhubung }\end{array}$ & - & 9 & 9 & 10 & 810 & 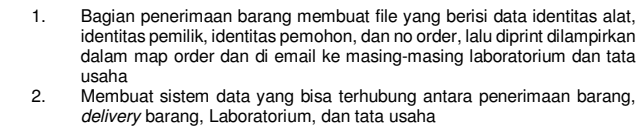 \\
\hline 12 & $\begin{array}{l}\text { Pengolahan data: } \\
\text { Input manual data identifikasi } \\
\text { alat } \\
\text { Input manual data no order }\end{array}$ & $\begin{array}{l}\text { Pergerakan berlebih } \\
\text { (waste jenis motion) }\end{array}$ & Pekerjaan tidak efisien & $\begin{array}{l}\text { Data dalam sistem penerimaan } \\
\text { barang belum terhubunng dengan } \\
\text { bagian laboratorium }\end{array}$ & - & 9 & 9 & 10 & 810 & $=$ no. 11 \\
\hline
\end{tabular}


Tabel 5. FMEA Sebelum diurutkan Berdasarkan RPN (Lanjutan)

\begin{tabular}{|c|c|c|c|c|c|c|c|c|c|c|}
\hline \multirow{2}{*}{ No } & \multirow{2}{*}{ Proses } & \multirow{2}{*}{$\begin{array}{l}\text { Mode Kegagalan } \\
\text { Potensial }\end{array}$} & \multirow{2}{*}{$\begin{array}{c}\text { Akibat Potensial dari Mode } \\
\text { Kegagaalan } \\
\end{array}$} & \multirow{2}{*}{$\begin{array}{l}\text { Penyebab Potensial dari } \\
\text { Kegagalan }\end{array}$} & \multicolumn{4}{|c|}{ Keadaan Sekarang } & \multirow{2}{*}{$\begin{array}{l}\text { Risk Priority } \\
\text { Number (RPN) }\end{array}$} & \multirow{2}{*}{ Usulan Tindakan Perbaikan } \\
\hline & & & & & Pengendalian yang dilakukan & Occ & Sev & Det & & \\
\hline \multicolumn{11}{|c|}{ Tata Usaha } \\
\hline 13 & $\begin{array}{l}\text { Membuat konsep sertifikat: } \\
\text { - Input manual data identitas } \\
\text { pemohon } \\
\text { - Input manual data identitas } \\
\text { pemilik } \\
\text { - Input manual data identitas } \\
\text { alat } \\
\text { - Input manual no order } \\
- \text { Input manual data dari } \\
\text { cerapan }\end{array}$ & $\begin{array}{l}\text { Pergerakan berlebih } \\
\text { (waste jenis motion) }\end{array}$ & Pekerjaan tidak efisien & $\begin{array}{l}\text { Datat dalam sistem penerimaan } \\
\text { barang belum terhubungn dengan } \\
\text { bagian tata usaha }\end{array}$ & & 9 & 9 & 10 & 810 & 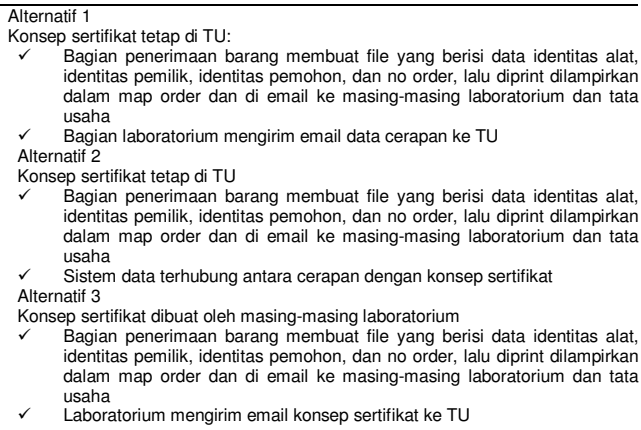 \\
\hline 14 & Proses di tata usaha & terlambat & $\begin{array}{l}\text { Keterlambatan wakku pelayanan } \\
\text { kalibrasi/ verifikasi }\end{array}$ & Kurang pegawai & Mengajukan penambahan pegawai & 8 & 8 & 10 & 640 & Mengusukan penambahan pegawai di Tata Usaha \\
\hline 15 & Membuat konsep sertifikat & terlambat & $\begin{array}{l}\text { Keterlambatan waktu pelayanan } \\
\text { kalibrasi/ verifikasi }\end{array}$ & $\begin{array}{l}\text { Aktivitas relatifi lebih banyak } \\
\text { karena input data masih manual }\end{array}$ & - & 9 & 9 & 10 & 810 & $=$ no. 11 \\
\hline 16 & $\begin{array}{l}\text { Verifikasi konsep sertifikat oleh } \\
\text { masing-masing laboratorium }\end{array}$ & terlambat & $\begin{array}{l}\text { Keterlambatan waktu pelayanan } \\
\text { kalibrasi/ verfitikasi }\end{array}$ & $\begin{array}{l}\text { Aktivitas relatif lebih banyak } \\
\text { akerena verifikasi konsep sertififat } \\
\text { ke masing-masing laboratorium }\end{array}$ & & 9 & 9 & 10 & 810 & Konsep sertifikat dibuat oleh masing-masing laboratorium \\
\hline 17 & $\begin{array}{l}\text { Verifikasi konsep sertifikat } \\
\text { oleh masing-masing laboratotorium }\end{array}$ & $\begin{array}{l}\text { NVA jenis excess } \\
\text { processing dan } \\
\text { transportation }\end{array}$ & Proses lebih lama & $\begin{array}{l}\text { Data cerapan berasal dari } \\
\text { laboratorium }\end{array}$ & - & 9 & 9 & 10 & 810 & $=$ no. 16 \\
\hline \multicolumn{11}{|c|}{ Penerimaan Barang, Delivery Barang, Laboratorium, Dan Tata Usaha } \\
\hline 18 & $\begin{array}{l}\text { Proses di Penerimaan Barang, } \\
\text { delivery barang, Laboratoorium, dan } \\
\text { tata usaha }\end{array}$ & $\begin{array}{l}\text { Waktu penyelesaian } \\
\text { order lebih dari yang } \\
\text { dijanjikan }\end{array}$ & $\begin{array}{l}\text { Keterlambatan wakku pelayanan } \\
\text { kalibrasi// verifikasi }\end{array}$ & $\begin{array}{l}\text { Perhitungan waktu penyelesaian } \\
\text { order belum memperyitungkan } \\
\text { inventory } \text { marena belum adanya } \\
\text { analisis kapasitas laboratorium }\end{array}$ & 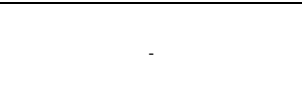 & 10 & 10 & 10 & 1000 & $\begin{array}{ll}1 . & \text { Mengajukan perubahan waktu penyelesaian order yang tadinya } 10 \text { hari } \\
\text { keria setelah tanggal kwitansi menjiadi } 30 \text { hari keria setelah tanggal } \\
\text { Kwintansiat } \\
2 . \quad \text { Membuat sistem penerimaan barang yang dapat menghitung waktu } \\
\text { penyelesaian order dengan memperhitungkan inventory }\end{array}$ \\
\hline 19 & $\begin{array}{l}\text { - Pengolahan data di } \\
\text { Laboratorium Mata } \\
\text { TU Membuat konsep sertifikat di } \\
\text { TU }\end{array}$ & Salah ketik & Kesalahan penulisan pada sertifikat & $\begin{array}{l}\text { Input data masih manual karena } \\
\text { sistem belum terhubung }\end{array}$ & & 8 & 8 & 10 & 640 & $=$ no. 11 \\
\hline 20 & $\begin{array}{l}\text { Pengolahan data di } \\
\text { Laboratorium Mata } \\
\text { TU Membuat konsep sertifikat di } \\
\text { TU }\end{array}$ & Salah ketik & Kesalahan penulisan pada sertifikat & $\begin{array}{l}\text { formulir pendaftaran belum di } \\
\text { check list karena kurang teliti }\end{array}$ & $\begin{array}{l}\text { Menghimbau agar pegawai } \\
\text { melakukan checklist dan yakin akan } \\
\text { kebenaran data yang ditulis }\end{array}$ & 8 & 8 & 8 & 512 & $\begin{array}{l}\text { Melaksanakan sosialisasis kepada pegawai terkait (penerimaan barang, delivery } \\
\text { barang, laboratorium, dan tata usaha) mengenai pentingnya kebenaran data di } \\
\text { awal }\end{array}$ \\
\hline 21 & $\begin{array}{l}\text { Pengolahan data di } \\
\text { Laboratorium } \\
\text { MUmbuat konsep sertifikat di } \\
\text { TU }\end{array}$ & Salah ketik & Kesalahan penulisan pada sertifikat & formulir ditulis tangan & & 8 & 8 & 10 & 640 & $\begin{array}{l}\text { Menyediakan form pendaftaran di websitite agar dapat di download oleh } \\
\text { pelanggan agar dapat diketik terlebih dahulu }\end{array}$ \\
\hline
\end{tabular}


Analisis selanjutnya dengan menggabungkan Tabel 4. identifikasi pemborosan dan identifikasi penyebab yang ada dalam fishbone (Gambar 2 dan Gambar 3) ke dalam FMEA (Tabel 5). FMEA menganalisis semua proses yang berpotensi menghasilkan Akibat Potensial dari Mode Kegagalan berupa pemborosan, keterlambatan waktu pelayanan verifikasi/ kalibrasi dan kesalahan penulisan pada sertifikat sehingga di dalam FMEA juga tercakup semua usulan tindakan perbaikan untuk meminimasi pemborosan, keterlambatan waktu pelayanan verifikasi dan kesalahan penulisan pada sertifikat (dari 2 CTS menjadi 3 CTS). Secara umum usulan perbaikan yang diberikan sama tetapi dapat menjawab permasalahan-permasalahan yang berbeda, misalnya usulan no 11.

\section{Fase Improve}

FMEA (Tabel 5) diurutkan mulai dari RPN tertinggi, sehingga kita dapat mengetahui usulan tindakan perbaikan sesuai dengan prioritas. Setelah itu dibuat rekapitulasi usulan perbaikan. Berdasarkan rekapitulasi ini, ada ada 3 rekomendasi yang dilaksanakan di tahun 2019 yaitu (1) mengubah waktu penyelesaian order semula 10 hari kerja dari tgl kwitansi menjadi 30 hari, (2) ada penambahan 1 orang pegawai di Laboratorium Panjang dan (3) Map order dan Standar/alat masuk laboratorium max $\mathrm{H}+1$. Ketiga rekomendasi di atas semuanya berhubungan dengan CTS 1 (belum menyentuh CTS 2 dan CTS 3). Dari segi VSM tidak banyak berubah, waktu di laboratorium dan tata usaha serta jumlah pegawai di Laboratorium Panjang saja yang mengalami perubahan. Namun dalam pelaksanaannya usulan no (1) belum dapat dijalankan secara konsisten, sehingga analisis selanjutnya untuk melihat pengaruh rekomendasi no (2) dan (3) terhadap kinerja laboratorium, dimana target waktu penyelesaian di laboratorium 7 hari kerja setelah tanggal kwitansi, hal ini sama baik untuk tahun 2018 maupun 2019. Untuk itu dilakukan perhitungan dan perbandingan level sigma antara tahun 2018 dengan 2019 dan uji hipotesis. Selain itu dilakukan analisis untuk mengevaluasi target waktu (7 hari di laboratorium, 3 hari di TU, 30 hari penyelesaian order) dan analisis kapasitas laboratorium secara kasar sebagai panduan bagi bagian penerimaan barang dalam menerima order.

Jika dibandingkan perhitungan level sigma tahun 2018 dengan 2019 (Tabel 3 dan Tabel 6), secara keseluruhan kinerja laboratorium di tahun 2019 mengalami peningkatan dibanding tahun 2018, walau ada penurunan di bulan September November, namun secara rata-rata, level sigma tahun 2019 sebesar 1,84 (probabilitas cacat/ terlambat masih sebesar 0,36693 atau PPM sebesar 366.930 , artinya ada 366.930 cacat dalam 1 juta kesempatan) lebih besar daripada tahun 2018 yaitu sebesar 1,43 (probabilitas cacat atau terlambat sebesar 0,5279 atau PPM sebesar 527.900), artinya proporsi tidak cacat meningkat, sebaliknya proporsi cacat menurun di tahun 2019. Terjadi pengurangan jumlah cacat sebesar $527.900-366.930=160.970$ dalam 1 juta kesempatan.

Tabel 6. Perhitungan Level Sigma dari Kinerja Laboratorium 2019

\begin{tabular}{|c|c|c|c|c|c|c|c|c|}
\hline Bulan & $\begin{array}{c}\text { Jumlah } \\
\text { Cacat } \\
\text { [2] }\end{array}$ & $\begin{array}{c}\text { Jml } \\
\text { tidak } \\
\text { Cacat } \\
\text { [3] }\end{array}$ & $\begin{array}{c}\text { Jumlah } \\
\text { sertifikat } \\
{[4]}\end{array}$ & $\begin{array}{c}p \\
\text { (cacat) } \\
{[2] /[4]} \\
{[5]}\end{array}$ & $\begin{array}{c}\text { p (tidak } \\
\text { cacat) } \\
1-[5] \\
{[6]}\end{array}$ & $\begin{array}{c}\text { PPM } \\
{[5] \times} \\
1000000 \\
{[7]}\end{array}$ & $\begin{array}{l}\text { NORM.S.INV [6] } \\
{[8]}\end{array}$ & $\begin{array}{c}{[8]+1,5} \\
{[9]}\end{array}$ \\
\hline Jan & 103 & 240 & 343 & 0,3003 & 0,69971 & 300.292 & 0,52 & 2,02 \\
\hline Feb & 235 & 238 & 473 & 0,4968 & 0,50317 & 496.829 & 0,01 & 1,51 \\
\hline Mar & 155 & 289 & 444 & 0,3491 & 0,65090 & 349.099 & 0,39 & 1,89 \\
\hline Apr & 22 & 251 & 273 & 0,0806 & 0,91941 & 80.586 & 1,40 & 2,90 \\
\hline Mei & 79 & 229 & 308 & 0,2565 & 0,74351 & 256.494 & 0,65 & 2,15 \\
\hline Juni & 12 & 269 & 281 & 0,0427 & 0,95730 & 42.705 & 1,72 & 3,22 \\
\hline Juli & 116 & 362 & 478 & 0,2427 & 0,75732 & 242.678 & 0,70 & 2,20 \\
\hline Agt & 109 & 487 & 596 & 0,1829 & 0,81711 & 182.886 & 0,90 & 2,40 \\
\hline Sept & 510 & 336 & 846 & 0,6028 & 0,39716 & 602.837 & $-0,26$ & 1,24 \\
\hline Okt & 701 & 180 & 881 & 0,7957 & 0,20431 & 795.687 & $-0,83$ & 0,67 \\
\hline Nov & 425 & 134 & 559 & 0,7603 & 0,23971 & 760.286 & $-0,71$ & 0,79 \\
\hline Des & 438 & 232 & 670 & 0,6537 & 0,34627 & 653.731 & $-0,40$ & 1,10 \\
\hline \multirow{2}{*}{$\begin{array}{c}\text { Total } \\
\text { Rata- } \\
\text { rata }\end{array}$} & 2905 & 3247 & 6152 & & & & & \\
\hline & 242 & 271 & 513 & & & & & 1,84 \\
\hline
\end{tabular}


Untuk lebih memastikan bahwa memang terjadi peningkatan kinerja laboratorium di tahun 2019 maka dilakukan uji hipotesis berupa uji proporsi berikut ini:

1. Parameter: proporsi cacat populasi sebelum perubahan ( $\mathrm{p} 1)$ dan setelah perubahan $(\mathrm{p} 2)$.

2. $H_{0}: p 1=p 2$

3. $H_{1}: p 1>p 2$

4. $\alpha=0,05 \quad Z_{\text {tabel }}=1,645$

5. Menghitung $Z_{0}$

$$
\begin{aligned}
& Z_{0}=\frac{\hat{p}_{1}-\hat{p}_{2}}{\sqrt{\hat{p}(1-\hat{p})\left(\frac{1}{n_{1}}+\frac{1}{n_{2}}\right)}} \\
& \hat{p}=\frac{X_{1}+X_{2}}{n_{1}+n_{2}} \\
& \hat{p}=\frac{2917+2905}{5227+6152} \\
& \hat{p}=0,5116
\end{aligned}
$$

Tabel 7. Control Plan untuk Tahun 2020

\begin{tabular}{lccc}
\hline \multicolumn{1}{c}{ CTS } & No & RPN & \multicolumn{1}{c}{ Rekomendasi } \\
\hline $\begin{array}{l}\text { Meminimasi } \\
\text { keterlambatan } \\
\text { waktu } \\
\text { pelayanan } \\
\text { kalibrasi/ } \\
\text { verifikasi }\end{array}$ & 1 & 1000 & $\begin{array}{l}\text { 1. Mengajukan perubahan waktu penyelesaian } \\
\text { order yang tadinya 10 hari kerja setelah } \\
\text { tanggal kwitansi menjadi } 30 \text { hari kerja } \\
\text { setelah tanggal kwitansi. }\end{array}$ \\
& & & $\begin{array}{l}\text { 2. Membuat sistem penerimaan barang yang } \\
\text { dapat menghitung waktu penyelesaian order } \\
\text { dengan memperhitungkan inventory } \\
\text { Menghimbau kepada pelangan swasta agar } \\
\text { mengkalibrasikan alatnya di awal tahun } \\
\text { (Januari-Juli) } \\
\text { Mengajukan penambahan pegawai }\end{array}$
\end{tabular}

4810 1. Map order dan Standar/alat masuk 1. Ada orang yang diberi tanggung jawab mengawasi laboratorium max $\mathrm{H}+1$

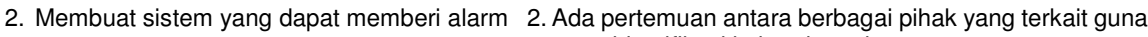
mengidentifikasi kebutuhan sistem

5810 1. Bagian penerimaan barang membuat file yang berisi data identitas alat, identitas
pemilik, identitas pemohon, dan no order, lalu di print dilampirkan dalam map order dan di email ke masing-masing laboratorium dan tata usaha

2. Membuat sistem data yang bisa terhubung antara penerimaan barang, delivery, barang, Laboratorium, dan tata usaha

6810 Konsep sertifikat dibuat oleh masing-masing laboratorium

$\checkmark$ Bagian penerimaan barang membuat file yang berisi data identitas alat, identitas pemilik, identitas pemohon, dan no order, lalu di print dilampirkan dalam map order dan di email ke masing-masing laboratorium dan tata usaha

$\checkmark \quad$ Laboratorium mengirim email konsep sertifikat ke TU
$Z_{0}=9,131025$

Karena $Z_{0}>Z_{\text {tabel, }}$ artinya $Z 0$ ada di daerah enolakan $\mathrm{H}_{0}$, dengan demikian $\mathrm{H}_{0}$ ditolak dan (iterima. Jadi p1 > p2, proporsi cacat enar daripada proporsi cacat enerapan usulan. Atau dengan kata usulan perbaikan dapat mengurangi oporsi cacat secara signifikan.

Agar perbaikan kualitas dapat berjalan secara continue, maka dibuatlah Control Plan (Tabel 7) dan Future VSM (Gambar 4) sebagai panduan. Dari Control Plan (Tabel 7), terlihat ada dapat berjalan sesuai yang diinginkan
. Bagian ini harus benar-benar teliti, bila perlu dilakukan rolling agar tidak jenuh.

2. Ada pertemuan antara berbagai pihak yang terkait guna mengidentifikasi kebutuhan sistem

- Jika belum ada penambahan pegawai maka perlu penambahan target waktu di laboratorium menjadi 10 hari kerja karena adanya penambahan aktivitas

- Diawasi dengan melakukan analisis mean waktu laboratorium, analisis mean waktu TU dan perhitungan level sigma 
Tabel 7. Control Plan untuk Tahun 2020 (Lanjutan)

\begin{tabular}{|c|c|c|c|c|}
\hline CTS & No & RPN & Rekomendasi & Control Plan \\
\hline Meminimasi & 7 & 810 & $=$ no. 5 & $=$ no 5 \\
\hline \multirow[t]{2}{*}{$\begin{array}{l}\text { kesalahan } \\
\text { penulisan } \\
\text { pada sertifikat }\end{array}$} & 8 & 576 & $\begin{array}{l}\text { Menyediakan form pendaftaran di website agar } \\
\text { dapat di download oleh pelanggan agar dapat } \\
\text { diketik terlebih dahulu }\end{array}$ & $\begin{array}{l}\text { Ada pertemuan antara berbagai pihak yang terkait guna } \\
\text { mengidentifikasi kebutuhan sistem }\end{array}$ \\
\hline & 9 & 512 & $\begin{array}{l}\text { Melaksanakan sosialisasi kepada pegawai } \\
\text { terkait (penerimaan barang, delivery barang, } \\
\text { laboratorium, dan tata usaha) mengenai } \\
\text { pentingnya kebenaran data di awal }\end{array}$ & Bisa disosialisasikan setiap rapat intern \\
\hline Meminimasi & 10 & 810 & $=$ no. 6 & $=$ no. 6 \\
\hline \multirow{5}{*}{ pemborosan } & 11 & 810 & $=$ no. 5 & $=$ no. 5 \\
\hline & 12 & 560 & $\begin{array}{l}\text { Bagian penerimaan barang menerbitkan form } \\
\text { yang berisi data-data yang dibutuhkan saat } \\
\text { serah terima barang }\end{array}$ & $\begin{array}{l}\text { Bagian ini harus benar-benar teliti, bila perlu dilakukan } \\
\text { rolling agar tidak jenuh }\end{array}$ \\
\hline & 13 & 504 & $\begin{array}{l}\text { Usul peningkatan kecepatan dan kapasitas } \\
\text { perangkat komputer yang ada }\end{array}$ & Usul penganggaran di tahun 2020 \\
\hline & 14 & 490 & $=$ no. 8 & $=$ no.8 \\
\hline & 15 & 441 & $\begin{array}{l}\text { Sosialisasi ke pelanggan agar membawa } \\
\text { sertifikat lama pada saat pendaftaran agar } \\
\text { proses input dapat lebih cepat }\end{array}$ & $\begin{array}{l}\text { Bisa dilakukan pada saat temu pelanggan atau email ke } \\
\text { masing-masing pelanggan }\end{array}$ \\
\hline
\end{tabular}

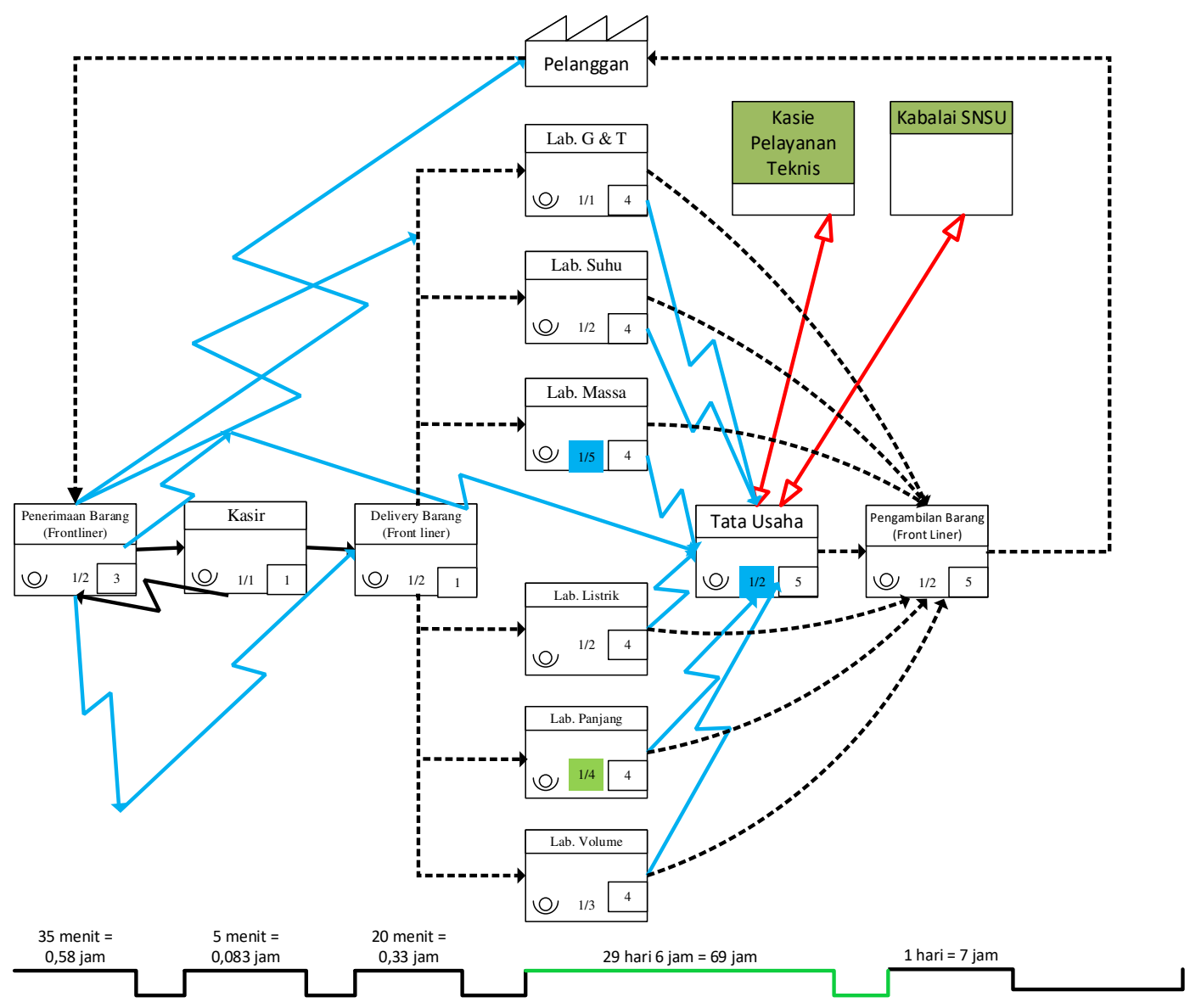

Gambar 4. Future VSM

Secara visual, pelayanan kalibrasi/ verifikasi yang akan dituju dapat dilihat pada Future VSM (Gambar 4 ). Pada Future VSM, perubahan utama terletak pada aliran informasi dan jumlah pegawai di Laboratorium Massa dan Tata usaha. Aliran informasi yang berusaha diubah yaitu yang tadinya manual menjadi elektronik (digambar berwarna biru)

\section{KESIMPULAN}

Penyebab utama keterlambatan waktu pelayanan kalibrasi/ verifikasi ini yaitu waktu penyelesaian order lebih dari yang dijanjikan. Hal ini terjadi karena adanya keterlambatan proses (bagian delivery barang, masing masing laboratorium dan Tata usaha) dan waktu penyelesaian order belum memperhitungkan 
inventory. Dilihat dari prinsip Lean, ada 12 waste (9 motion, 3 waiting), dan 3 non value added (2 excess processing, 1 transportation) yang ada dalam value stream pelayanan verifikasi/ kalibrasi. Analisis perbaikan mampu memberikan 15 rekomendasi dalam bentuk control plan berdasarkan siklus DMAIC. Integrasi data identifikasi pemborosan yang berasal dari VSM dan Diagram Fishbone ke dalam FMEA memperoleh perbaikan dan analisis yang lebih komprehensif.

\section{DAFTAR PUSTAKA}

Antony, J., Rodgers, B., \& Cudney, E. A. (2017). Lean Six Sigma for public sector organizations: is it a myth or reality? International Journal of Quality \& Reliability Management, 34(9), 1402-1411. https://doi.org/10.1108/IJQRM-08-20160127

Antony, J., Rodgers, B., \& Gijo, E. V. (2016). Can Lean Six Sigma make UK public sector organisations more efficient and effective? International Journal of Productivity and Performance Management, 65(7), 9951002. https://doi.org/10.1108/IJPPM-032016-0069

Antony, J., Snee, R., \& Hoerl, R. (2017). Lean Six Sigma: yesterday, today and tomorrow. International Journal of Quality \& Reliability Management, 34(7), 1073-1093. https://doi.org/10.1108/IJQRM-03-20160035

CNN Indonesia. (2019). Survei Kepatuhan Ombudsman, Banyak Pemda Dapat Rapor Merah.

https://www.cnnindonesia.com/nasional/201 91127124804-20-451937/survei-kepatuhanombudsman-banyak-pemda-dapat-rapormerah

El-Haik, K. Y.-B., \& Yang, K. (2003). Design for Six Sigma, A Roadmap for Product Development (Vol. 21). The McGraw-Hill Companies, Inc.

Fletcher, J. (2018). Opportunities for Lean Six Sigma in public sector municipalities. International Journal of Lean Six Sigma, 9(2), 256-267. https://doi.org/10.1108/lJLSS-07-2017-0086

Furterer, S. L. (2009). Lean Six Sigma in service: applications and case studies. CRC press.

Hayler, R., \& Nichols, M. (2006). Six sigma for financial services: how leading companies are driving results using lean, six sigma, and process management. McGraw Hill Professional.

Mahsyar, A. (2011). Masalah Pelayanan Publik di Indonesia dalam Perspektif Administrasi
Publik. Otoritas: Jurnal IImu Pemerintahan, 1(2), 81-90. https://journal.unismuh.ac.id/index.php/Otori tas/article/view/22

Mättö, T. (2019). Innovation through implementation of a quality improvement method. The TQM Journal, 31(6), 987-1002. https://doi.org/10.1108/TQM-12-2018-0193

Munro, R. A., Ramu, G., \& Zrymiak, D. J. (2015). The certified six sigma green belt handbook. Quality Press.

Panuti, S., Anggraeni, S. K., \& Bahauddin, A. (2013). Rancangan Perbaikan Kualitas Layanan Poliklinik Kulit dan Kelamin RSUD Cilegon dengan Pengintegrasian Metode Servqual, Lean dan Six Sigma. Jurnal Teknik Industri Untirta, 1(2), 169-173. https://jurnal.untirta.ac.id/index.php/jti/article /view/139

Peraturan Menteri Pendayagunaan Aparatur Negara. (2009). Peraturan Menteri Pendayagunaan Aparatur Negara Nomor 13 Tahun 2009 tentang Pedoman Peningkatan Kualitas Pelayanan Publik Dengan Partisipasi Masyarakat. Jakarta: Kementerian Negara Pendayagunaan Aparatur Negara. http://jdih.menpan.go.id/data_puu/44 final.pdf

Presiden Republik Indonesia. (2012). Peraturan Pemerintah Republik Indonesia Nomor 96 Tahun 2012 tentang Pelaksanaaan UndangUndang Nomor 25 Tahun 2009 Tentang Pelayanan Publik. Jakarta: Sekretariat Negara.

https://jdih.bsn.go.id/produk/detail/?id=384\& jns $=4$

Rodgers, B., \& Antony, J. (2019). Lean and Six Sigma practices in the public sector: a review. International Journal of Quality \& Reliability Management, 36(3), 437-455. https://doi.org/10.1108/IJQRM-02-20180057

Rucker, R. (2000). Citibank increases customer loyalty with defect-free processes. The Journal for Quality and Participation, 23(4), 32-36.

https://search.proquest.com/openview/3245 febf0139096aa09208d650ee150b/1?pqorigsite $=$ gscholar $\& \mathrm{cbl}=37083$

Sunder M., V. (2016). Rejects reduction in a retail bank using Lean Six Sigma. Production Planning \& Control, 27(14), 1-12. https://doi.org/10.1080/09537287.2016.118 7312

Sunder M., V., Ganesh, L. S., \& Marathe, R. R. (2019). Lean Six Sigma in consumer banking 
- an empirical inquiry. International Journal of Quality \& Reliability Management, 36(8), 1345-1369. https://doi.org/10.1108/IJQRM01-2019-0012

Trakulsunti, Y., Antony, J., Dempsey, M., \& Brennan, A. (2020). Reducing medication errors using lean six sigma methodology in a Thai hospital: an action research study. International Journal of Quality \& Reliability Management, ahead-of-p(ahead-of-print). https://doi.org/10.1108/IJQRM-10-20190334

Undang-Undang Republik Indonesia. (2009). Undang-undang Republik Indonesia nomor 25 tahun 2009 tentang Pelayanan Publik. Jakarta: Republik Indonesia. https://jdih.kemenkeu.go.id/fulltext/2009/25T AHUN2009UUPenj.htm

Wahidi, A. (2019). Rapor Pelayanan Publik Tahun 2019.

https://ombudsman.go.id/artikel/r/artikel-rapor-pelayanan-publik-tahun-2019 